\title{
シフト試薬を用いる飽和及び不飽和脂肪酸メチル エステルの核磁気共鳴スペクトル
}

\author{
野田万次郎・高 橋 朋 弘 \\ 京都府立大学農学部農芸化学科 (京都市左京区下鴨半木町)
}

\author{
NMR Analysis of Saturated and Unsaturated Fatty Acid \\ Methyl Esters by Using Shift Reagents
}

\author{
Manjiro Noda and Tomohiro TAKahashi \\ Department of Agricultural Chemistry, College of Agriculture, \\ Kyoto Prefectural University (Shimogamo, Sakyo-ku, Kyoto)
}

The effect of relative concentration of shift reagents, $\mathrm{Eu}(\mathrm{fod})_{3}$ and $\operatorname{Pr}(\mathrm{fod})_{3}$, on the proton chemical shifts of the methyl esters of saturated, oleic, petroselinic, erucic, linoleic, linolenic, and stearolic acids was represented as figures comparable with one another.

The shift reagent, $\operatorname{Pr}(\mathrm{fod})_{3}$, was superior to $\mathrm{Eu}(\mathrm{fod})_{3}$ in complete separation of the signals for olefinic and the neighporing methylene protons from those for the other methyl and methylene protons. Estimation of total unsaturated fatty acids in fatty acid mixtures was possible by calculation from the integrated areas of two peaks (methoxycarbonyl methyl and non-diallylic $\alpha$-methylene to double bonds) isolated as the result of the $\operatorname{Pr}(\mathrm{fod})_{3}$-induced shift.

Difference in the induced shift between the methoxycarbonyl methyl protons of methyl oleate and petroselinate was observed. By the use of the induced shift, methyl petroselinate in mixed methyl esters could also be determined from the integrated areas of the separated singlets for the methoxy= carbonyl methyl protons, the isolated multiplet for C-6 olefinic proton, and a peak for methylene protons near ester linkage.

\section{1 緒 言}

ランタノイドシフト陚薬は, 近年 NMR スペクトル 法の分野でよく使わ机るようになってきたが，特に脂質 のような長鎖化合物の構造解析には，今後ますます有力 な手段になるものと思わ礼る。長鎖脂肪酸エステルに関 するプロトンNMRの範囲に限ってみても, 飽和, 不飽 和脂肪酸メチルエステル12 文，ヒドロキシ酸及びエポキ シ酸メチルエステル5),6)，アシルオキシポリアセチレン 酸メチルエステル ${ }^{7)}$, 脂肪酸エステル過酸化物 ${ }^{8)}$, トリグ リセリド9 14)などの研究に利用された例がある。

しかし，この方法を脂肪族長鎖化合物一般に広く，か つ効果的に応用してゅくためには，上記のような個々の 化合物だけでなく, 各種脂肪族長鎖化合物に実際にシフ 卜試薬を加えた場合の, 広範囲の，系統的かつ基礎的な データを必要とし，これらの結果の相互比較が簡単にで きることが望ましい，この報告では以上の見地から，ま
ず最も普通に見られる飽和，不飽和脂肪酸のメチルエス テルについて, シフト試薬を加えた場合の各プロトンの 化学シフト值の変化を相互比較できるような, 同一機器 による実用的な基礎資料を提供することを一つの目的と した。

また使用したシフト試薬は, トリス $(1,1,1,2,2,3,3-$ ヘプタフルオロ -7,7-ジメチル-4,6-オクタジオナト) ユ ウロピウム $(\mathrm{III})\left(\mathrm{Eu}(\mathrm{fod})_{3}\right)$ 及びトリス $(1,1,1,2,2$, 3,3-ヘプタフルオロ-7,7-ジメチル-4,6-オクタジオナ ト）プラセオジム (III) $\left(\operatorname{Pr}(\text { fod })_{3}\right)$ の両者であるが， 特に $\operatorname{Pr}(\text { fod })_{3}$ に関する結果注新しい知見も多く, 有益 であったので，その脂肪酸定量への応用ともあわせて， 比較的詳細に記述した。

\section{2 実験}

\section{$2 \cdot 1$ 試薬と試料エステル}

シフト試薬としては, 市販 $\mathrm{Eu}(\mathrm{fod})_{3}$ 及び $\operatorname{Pr}(\text { fod })_{3}$ 
(同仁薬化学製)を，五酸化リン上で減圧加温乾燥後， 五酸化リンの減圧デシケーター中で保存したものを使用 した。

試料として用いた飽和脂肪酸, ペトロセリン酸, エル 力酸は，いずれも市販品（純度 $99 \%$ 以上）を用い，才 レイン酸，リノール酸，及びリノレン酸のメチルエステ ルは，それぞれオリブ油，ごま油，及びあまに油から尿 素付加と低温分別結晶法で分離精製し，さらにシリカゲ ルー硝酸銀薄層クロマトグラフィー又は減圧蒸留法等を 用いて単離したものである。ステアロル酸は，オレイン 酸から調製したジブロモオクタデカン酸を, 水酸化カリ ウムと1ーブタノール中で加熱する常法によって得た。

遊離酸は三フッ化ホウ素ーメタノール溶液を用いてメ チルエステルとした。またグリセリドからの脂肪酸メチ ルエステルの調製は，ナトリウムメトキシド又は三フッ 化ホウ素ーメタノールを使うメタノリシス法によった。 いずれの標品脂肪酸も，そのメチルエステルの GLC 及 び TLC で純度を確認している。

NMR 用溶媒としては四塩化炭素を用い，内部標淮物 質としてテトラメチルシラン (TMS) を 1〜3\% の濃度 になる程度に添加している。

\section{$2 \cdot 2$ 装置と測定法}

使用装置法日立高分解能核磁気共鳴装置 R-24 型（60 $\mathrm{MHz})$ で，室温 $\left(16 \sim 30^{\circ} \mathrm{C}\right)$ で測定した。

試料メチルエステル 7〜30 $\mathrm{mg}$ に所定量のシフト試薬 を添加し，これを上記 TMS 含有四塩化炭素 $0.3 \sim 0.4$ $\mathrm{ml}$ に溶解した。ただし純品の陚料に対しては, シフト 試薬の溶解が可能なかぎり, 試料 $20 \mathrm{mg}$ に対し四塩化炭 素 $0.3 \mathrm{ml}$ を使うことを原則とした。この溶液を外径 4 $\mathrm{mm}$ の試料管に入れて測定している。

化学シフトは TMS を内部標準としたときの $\delta(\mathrm{ppm})$ 值で表し，TMS より高磁場側を負の值とした。

定量のための各ピークの積分值は，同一条件で $5 \sim 10$ 回繰り返して積分曲線を書かせ, 該当ピークの測定值の 平均值をとった。

\section{3 結 果}

\section{$3 \cdot 1$ 一般的特幑}

Fig.-1 に，リノール酸メチルにそれぞれ $\mathrm{Eu}(\mathrm{fod})_{3}$ 及び $\operatorname{Pr}(\mathrm{fod})_{3}$ を加えたときの NMR スペクトルを例 示する。いずれの試薬の場合も, メトキシカルボニル= メチル, $-\mathrm{CO}-\mathrm{OCH}_{3}$ (エステルメチルと略称), 又は -CO-に隣接する脂肪酸側の $\alpha$-メチレン基のプロトンの シグナルが最も大きく影響を受けて移動するが， Eu (fod) ${ }_{3}$ の低磁場側へのシフトに対し, $\operatorname{Pr}(\text { fod })_{3}$ の高磁 場側へのシフトが特徵的である。シグナル幅はシフト試 薬の添加とともに增大し, ピークの先鋭度が減少する傾 向にある。
$\mathrm{CH}_{3}\left(\mathrm{CH}_{2}\right)_{3} \mathrm{CH}_{2} \mathrm{CH}=\mathrm{CHCH}_{2} \mathrm{CH}=\mathrm{CHCH}_{2} \mathrm{CH}_{2} \mathrm{CH}_{2} \mathrm{CH}_{2} \mathrm{CH}_{2} \mathrm{CH}_{2} \mathrm{CH}_{2} \mathrm{COOCH}_{3}$

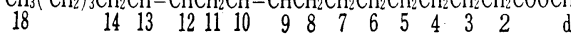

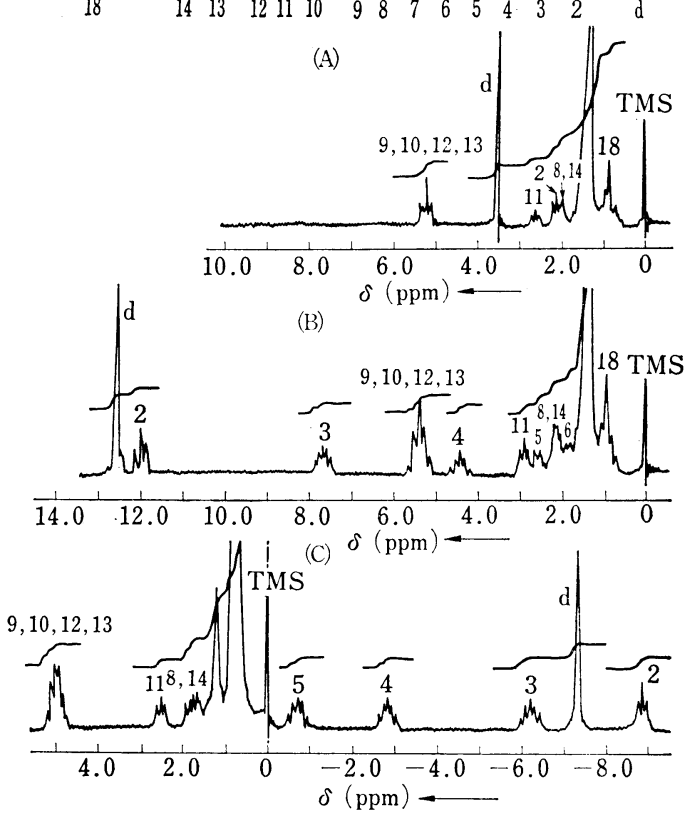

Fig.-1 NMR spectra $(60 \mathrm{MHz})$ of methyl linoleate (A), methyl linoleate containing $\mathrm{Eu}(\mathrm{fod})_{s}$ (B), and methyl linoleate containing $\operatorname{Pr}(\text { fod })_{3}$ (C). Molar ratio: Eu(fod) $)_{3} /$ ester $=1.57$, $\operatorname{Pr}(\text { fod })_{3} /$ ester $=0.78$.

シフト試薬添加のスペクトル中で，o 0.5 1.5 付近 に新たに現れる大きなピークは，シフト試薬のメチルプ ロトンによるもので, 添加比率が増大すると, 当然大き くなる。

内部標準として加えた TMS のシグナルも, 実際はシ フト試薬の添加によって, 外部標準の TMS 上比べる と，いずれも高磁場側にシフトしてくることが注目され

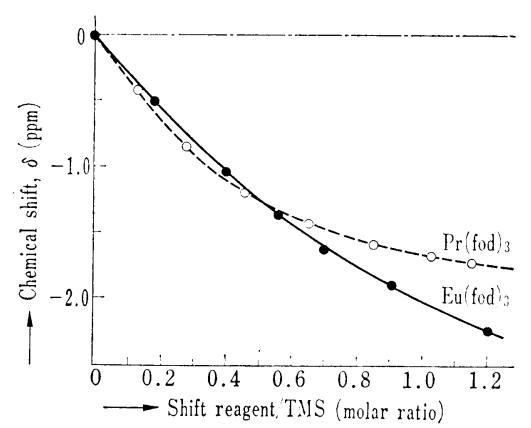

Fig.-2 Proton chemical shift plots obtained from incremental addition of shift reagents to TMS $(5 \mathrm{mg})$ in $\mathrm{CCl}_{4}(0.3 \mathrm{ml})$. The values are given as those on the basis of TMS without shift reagents. 
る（Fig.-2）。しかし前述のように，本報告では，常に 内部標準の TMS を基準（ $\left.\begin{array}{l}\delta \\ 0\end{array}\right)$ として測定した $\delta$ 值を 採用した。

\section{2 $\mathrm{Eu}(\mathbf{f o d})_{3}$ 添加の影響}

飽和, 不飽和脂肪酸メチルエステルに, 種々のモル比 で $\mathrm{Eu}(\mathrm{fod})_{3}$ を添加し，各プロトンシグナルの移動を 追ってみた。代表的な天然 $\mathrm{C}_{18}$ 脂肪酸メチルについて測 定された結果を Fig.-3 にまとめて例示する。

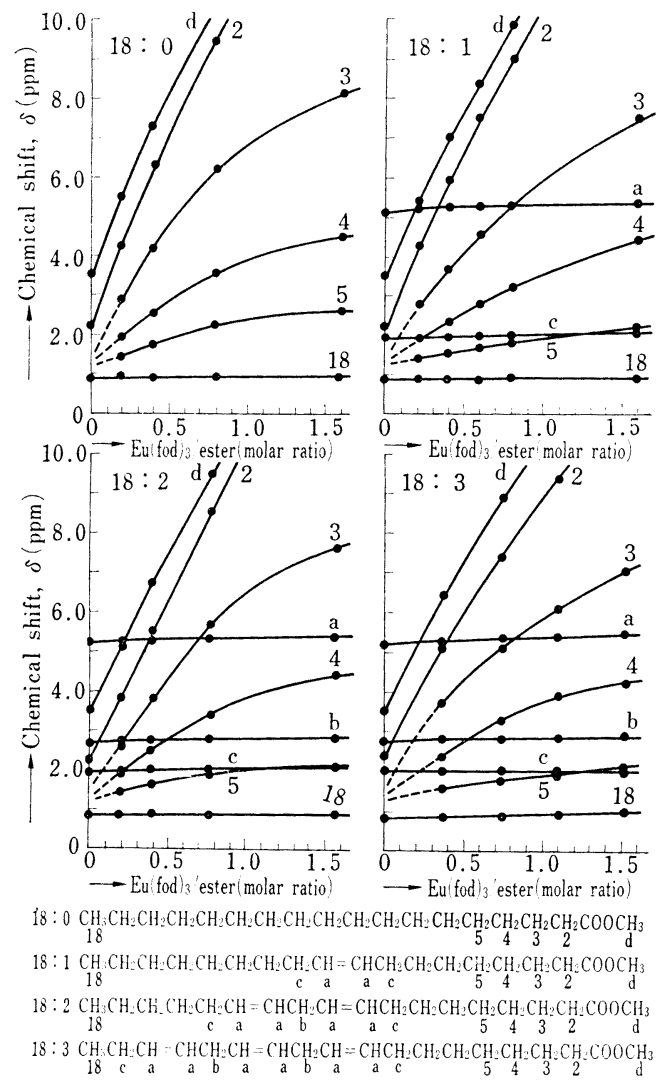

Fig.-3 Proton chemical shift plots for methyl stearate $(18: 0)$, methyl oleate $(18: 1)$, methyl linoleate $(18: 2)$, and methyl linolenate $(18: 3)$ with $\mathrm{Eu}(\text { fod })_{3}$.

この報告の条件では，アシル基の C-5 以下のメチレ ンプロトンの低磁場側へのシフトが顕著であり, それぞ れのメチレンプロトンのシグナルを判別できる。またオ レフィンプロトン $(\mathrm{a}, \delta 5.2$ 付近), 二重結合閒のメチ レン (ジアリル型) プロトン (b, o 2.7 付近), 二重結 合外側化隣接するメチレンプロトン (c, $\delta 2.0$ 付近), C-18 メチルプロトン ( $\delta 0.9$ 付近) 等の シグナルはほ とんど移動せず，明らかにその個々が区别できる。なお 以上以外のメチレンプロトン（ $\delta 1.3$ 付近）のシグナル はあまり移動せず，従ってシフト試薬添加後も重なった ピークとして残る。またエステルメチルプロトンの一重
線は前述のように最も大きくシフトしている。

これら図示された不飽和酸メチルの各相当プロトンの シフト傾向は相互に類似し，ジェン酸以上で認められる 二重結合間のメチレンプロトンのシグナル (b) が，才 レイン酸では欠如している程度の差が認めら机るにすぎ ない。

パルミチン酸その他の飽和酸メチルの場合もステアリ ン酸メチルと酷似する。エルカ酸メチル $[22: 1$ ( cis13)] はオレイン酸メチルの図と大体一致するが,ペトロ セリン酸メチル $[18: 1(c i s-6)]$ の場合は, 二重結合が カルボキシル基に比較的近くて影響を受けるため， Eu (fod) ${ }_{3}$ の添加に伴って, 二重結合雨側のメチンプロト ンのそれぞれが分離してくる2゙,3)。

三重結合を持つステアロル酸（9-オクタデシン酸）メ チルの場合は，Fig.-4 のようにオレイン酸メチルに類 似しているが，オレフィンプロトンがない点が当然異な る。三重結合両側の隣接プロトン (c，ò 2.1 付近) は判 別できる。

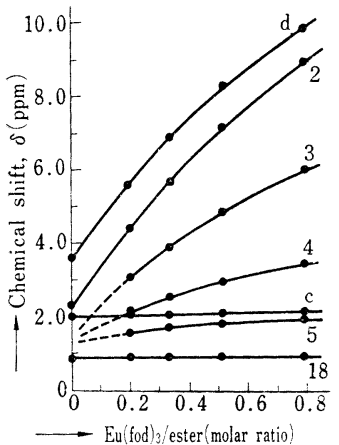

$\mathrm{CH}_{3}\left(\mathrm{CH}_{2}\right)_{6} \mathrm{CH}_{2} \mathrm{C} \equiv \mathrm{CCH}_{2}\left(\mathrm{CH}_{2}\right)_{2} \mathrm{CH}_{2} \mathrm{CH}_{2} \mathrm{CH}_{2} \mathrm{CH}_{2} \mathrm{COOCH}$

Fig.-4 Proton chemical shift plots for methyl stearolate with $\mathrm{Eu}(\text { fod })_{3}$.

\section{3 $\operatorname{Pr}(\text { fod })_{3}$ 添加の影響}

$\operatorname{Pr}(\text { fod })_{3}$ を加えると，一般に各プロトンのシグナル は高磁場側にシフトする。

Fig.-5 亿代表的な $\mathrm{C}_{18}$ 飽和, 不飽和酸メチルの各プ ロトンシグナルのシフトの状態を対比してあげる。本実 験の条件では, エステルメチルプロトン (d) とC-2〜C5 までのメチレンプロトンのシグナルが 内部標準 TMS の位置より高磁場に出て完全に区别できる。

$\operatorname{Pr}(\mathrm{fod})_{3} /$ エステルのモル比が 1.0 以下で注, 高磁場 方向へのシフトの程度は C-2>エステルメチル $>\mathrm{C}-3>$ C-4>C-5 の各プロトンの順であった。C-18 の末端メ チルプロトン，オレフィンプロトン (a)，及びそれに隣 接するメチレンプロトン (b, c) \& $\mathrm{Eu}(\text { fod })_{3}$ の場合と 同様に, シフト值の変化は微少である。従って低磁場側 には二重結合周辺のプロトンのシグナルのみが残り, TMS より高磁場側に移動したエステル結合近辺のメチ 


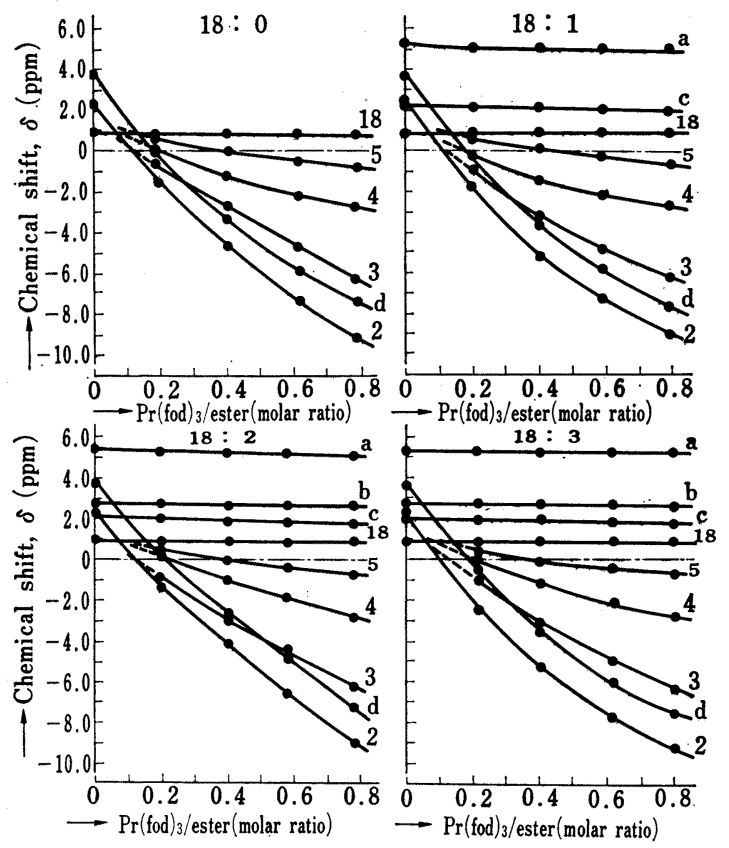

Fig.-5 Proton chemical shift plots for methyl stearate $(18: 0)$, methyl oleate $(18: 1)$, methyl linoleate $(18: 2)$, and methyl linolenate $(18: 3)$ with $\operatorname{Pr}(\text { fod })_{8}$. Carbon chain positions on fatty acid ester mole= cules are represented with the same numbers or symbols as in Fig. -3 .

ル,メチレンプロトンのものと完全に分離するので, 二 重結合周辺プロトンのピークの積分值を利用する定量に は, $\operatorname{Pr}(\mathrm{fod})_{3}$ を使う方が有利である。

ステアリン酸以外の飽和酸メチルは, ステアリン酸メ チルのシフト特性と基本的に同一である。またエルカ酸 メチルのものもオレイン酸メチルの図に酷似する, ペト ロセリン酸メチルについては, オレイン酸メチルのもの といくらか相違があり,これについては後述 (3.4.2) 寸 る。 $\operatorname{Pr}(\text { fod })_{3}$ は $\mathrm{Eu}$ (fod) $)_{3}$ に比べて, 許容添加モル比 が低いところに限定される。通常 $\operatorname{Pr}$ (fod $)_{3} /$ エステルの モル比が 1.0 以下が実用的で, それ以上ではシフト值の 顕著な変化は望めない。

\section{4 脂肪酸定量への応用}

$3 \cdot 4 \cdot 1$ 飽和酸と不飽和酸の含有比率

飽和酸とオレイン酸, リノール酸, リノレン酸等の最 も普通の脂肪酸から成る混合脂肪酸の場合, シフト試薬 を用いるNMR を利用して, 飽和酸と全不飽和酸のモル 百分率を求めることができる。例えば，混合脂肪酸メチ ルに $0.25 \sim 0.30$ 程度のモル比で $\operatorname{Pr}(\text { fod })_{3}$ を加えると, Fig.-6 のように, 二重結合周辺のプロトンとエステル 結合近边のプロトンのシグナルが分離するから， c のプ ロトン $(4 \mathrm{H}$, 積分值 $c)$ と d のプロトン $(3 \mathrm{H}$, 積分
値 $d$, 各脂肪酸メチルの $\mathrm{d}$ のシフト值は異なり, その一 重線は 3 本江分離）の積分值の比から, 飽和, 不飽和酸 モル百分率を算出することができる。

飽 和酸 $\%=100-\frac{75 c}{d}$

不飽和酸 $g=\frac{75 c}{d}$
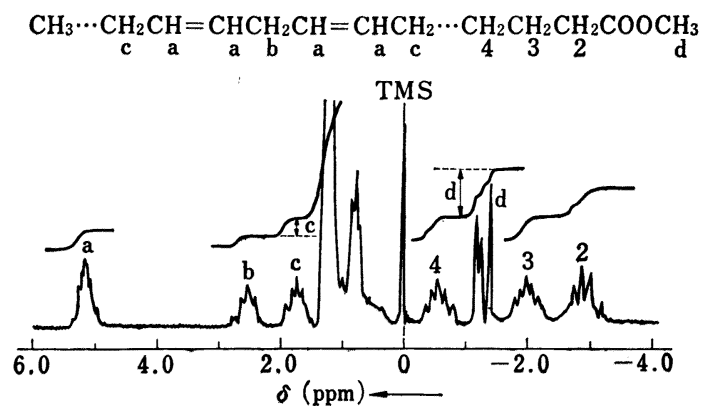

Fig.-6 NMR spectrum (60 $\mathrm{MHz})$ of a mixture of methyl palmitate, methyl oleate, methyl linoleate, and methyl linolenate with $\operatorname{Pr}\left(\right.$ fod $_{8}$. Molar ratio, $\operatorname{Pr}\left(\mathrm{fod}_{8} /\right.$ esters $=0.26$.

この方法を使い, 混合脂肪酸メチルについて定量を行 った例を，DEGS を固定液相とするガスクロマトグラ フィーの分析值と対比して Table-1 に示す。この表の ように, ガスクロマトグラフィーによる定量值との差は 著しくはないが GLC の微量性と信頼性には及ばない。

Table-1 Estimation of saturated and unsaturated fatty acids by NMR using $\operatorname{Pr}(\text { fod })_{8}$.

\begin{tabular}{|c|c|c|c|}
\hline \multirow{2}{*}{ Sample } & \multirow{2}{*}{ Method } & \multicolumn{2}{|c|}{$\begin{array}{l}\text { Fatty acid composition } \\
(\text { mol } \not 6)\end{array}$} \\
\hline & & Saturated & Unsaturated \\
\hline \multirow{3}{*}{$\begin{array}{l}\text { Mixture of } 16: 0 \text {, } \\
18: 1,18: 2 \text {, and } \\
18: 3\end{array}$} & (Weighed & 28.8 & 71.2 \\
\hline & $\{$ NMR & 29.7 & 70.3 \\
\hline & l GLC & 28.0 & 72.0 \\
\hline \multirow{2}{*}{ Cacao butter } & \{ NMR & 64.9 & 35.1 \\
\hline & GLC & 62.3 & 37.7 \\
\hline \multirow{2}{*}{ Olive oil } & \{ NMR & 13.9 & 86.1 \\
\hline & I GLC & 13.3 & 86.7 \\
\hline \multirow{2}{*}{ Soybean oil } & \{ NMR & 14.5 & 85.5 \\
\hline & I GLC & 13.6 & 86.4 \\
\hline
\end{tabular}

ただし本法は試料が回収できる利点がある。なお $\mathrm{Pr}$ (fod) ${ }_{3}$ の添加比によっては, 飽和酸と各不飽和酸のエス テルメチルプロトンシグナル（d）のシフト值がそれぞ れ異なり,ピークが分離する場合があるので, この場合 は理論的には, 飽和酸, モノー, ジー, トリエン酸の各脂 肪酸の百分率の算出が可能であるが, 実験の結果は, 充 分信頼のおける測定值が得られなかった。

$3 \cdot 4 \cdot 2$ ペトロセリン酸の定量

ペトロセリン酸を含む試料の場合，DEGS を使ら一 
般の GLC では，オレイン酸との分離が極めて困難であ る。この場合, $\operatorname{Pr}$ (fod) $)_{3}$ を加える $\mathrm{NMR}$ 分析を併用す ることによって，両者の定量が可能となることが判明し た。

ペトロセリン酸メチルに $\operatorname{Pr}(\mathrm{fod})_{3}$ を添加していくと Fig.-7 のように，C-6, C-7 のオレフィンプロトンのシ グナルは低磁場側にとどまり，かつ両者のシグナルは完

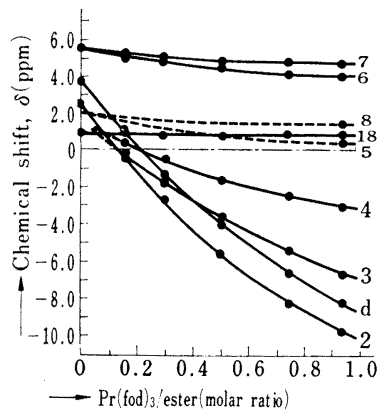

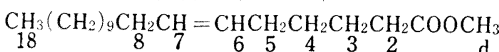

Fig.-7 Proton chemical shift plots for methyl petroselinate with $\operatorname{Pr}(\text { fod })_{3}$.

全に分離する。オレイン酸メチル（リノール酸メチルや リノレン酸メチルの場合も同様）とペトロセリン酸メチ ルの混合物では, 雨者のオレフィンプロトンもエステル メチルプロトン $(d)$ もそれぞれの相当するシグナルが 相互分離しないが (Fig.-8， A), $\operatorname{Pr}(\text { fod })_{3}$ を加えてい くと, 両脂肪酸メチルの各相当シグナルで，そのシフト 值に差が現れ，明確にピークが分離する (Fig.-8, B)。

分崔したピークを単一化合物についての実験結果と比

$\underset{18}{\mathrm{CH}_{3}}\left(\mathrm{CH}_{2}\right)_{-} \mathrm{CH}=\underset{9}{\mathrm{CH}}\left(\mathrm{CH}_{2}\right)_{4} \mathrm{CH}_{2} \mathrm{CH}_{3} \mathrm{CH}_{2} \mathrm{COOCH}_{2}$ Methyl oleate

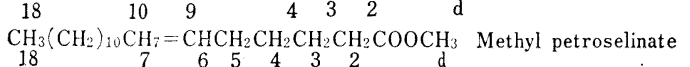

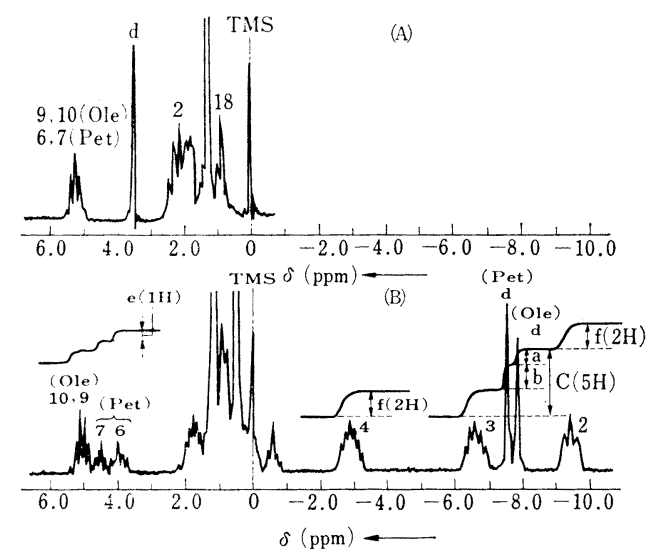

Fig.-8 NMR spectra $(60 \mathrm{MHz})$ of a mixture of methyl oleate and methyl petro= selinate without $\operatorname{Pr}(\text { fod })_{3}(A)$, and with $\operatorname{Pr}(\text { fod })_{3} \quad(B) . \quad \operatorname{Pr}(\text { fod })_{3} /$ esters $=0.84$. Ole, oleate; Pet, petroselinate.
較した結果, オレフィンプロトンのピークは, 低磁場側 よりオレイン酸メチルの C-9 及び 10, ペトロ七リン酸 メチルの C-7, 同 C-6 の順に 3 群に分離し, エステル メチルプロトン（d）泜低磁場側がペトロセリン酸メチ ル, 高磁場側がオレイン酸メチルのものであり, 両一重 線間の間隔は $\operatorname{Pr}(\text { fod })_{3} /$ エステル $=0.80$ 付近で約 $12 \mathrm{~Hz}$ であった。また脂肪酸側の C-2 C -4 は, $\operatorname{Pr}(\mathrm{fod})_{3}$ の 添加によっても相当するそれぞれのプロトンのピークは 相互分離しないが, 各脂肪酸によってわずかなシフト值 の差が生じ, その結果として多重線のシグナルの先鋭度 は減少する。

この Fig.-8, B に見られるようなシグナルの分離を 利用して, 各ピークの積分值からペトロセリン酸のモル 百分率を算出することができる（積分值 $a \sim f$ は Fig.-

8, B の記号 $\mathrm{a} \sim \mathrm{f}$ の測定值に対応する)。

オレイン酸とペトロセリン酸だけの混合物の場合,

$$
\text { ペトロセリン酸 } \%=\frac{100 b}{a+b}
$$

両脂肪酸以外飞他の脂肪酸も大っている場合,

$$
\text { ペトロセリン酸 } \%=\frac{500 e}{c}
$$

または

$$
\text { ペトロセリン酸 } \%=\frac{200 e}{f}
$$

なお定量の場合のシフト試薬の添加モル比は,

\begin{tabular}{|c|c|c|c|c|}
\hline \multirow{2}{*}{ Methyl esters } & \multirow{2}{*}{ Method* } & \multicolumn{3}{|c|}{ Fatty acid composition ( $\mathrm{mol} \%)$} \\
\hline & & Petroselinic & Oleic & Others \\
\hline \multirow{4}{*}{ Mixture I } & Weighed & 17.8 & 82.2 & \\
\hline & NMR (3) & 18.5 & 81.5 & \\
\hline & NMR (4) & 17.2 & 82.8 & \\
\hline & NMR (5) & 17.9 & 82.1 & \\
\hline \multirow{4}{*}{ Mixture II } & Weighed & 47.5 & 52.5 & \\
\hline & NMR (3) & 48.7 & 51.3 & \\
\hline & NMR (4) & 46.9 & 53.1 & \\
\hline & Oxidation & 48.5 & 51.5 & \\
\hline \multirow{5}{*}{ Mixture III } & Weighed & 59.3 & 40.7 & \\
\hline & NMR (3) & 60.0 & 40.0 & \\
\hline & NMR (4) & 60.6 & 39.4 & \\
\hline & NMR (5) & 58.3 & 41.7 & \\
\hline & Oxidation & 60.4 & 39.6 & \\
\hline \multirow{2}{*}{$\begin{array}{l}\text { Methyl esters } \\
\text { from carrot } \\
\text { seed triacyl } \\
\text { glycerols }\end{array}$} & / NMR (4) & 61.5 & \multicolumn{2}{|c|}{38.5} \\
\hline & Oxidation & 61.7 & 20.8 & 17.5 \\
\hline
\end{tabular}

Table-2 Estimation of methyl petroselinate by NMR using $\operatorname{Pr}(\text { fod })_{3}$.

* Numbers in parentheses indicate the numbers of equa $=$ tions employed, respectively (see text). Estimation by the oxidation method was carried out in combination with gas-liquid chromatography. The ratio of petroseli= nate to oleate in their overlapped peaks on gas-liquid chromatogram could be calculated from the ratio of lauric to nonanoic acid produced by a modified periodatepermanganate oxidation ${ }^{15), 16)}$. 
$\operatorname{Pr}(\text { fod })_{3} /$ エステル $=0.8 \sim 0.9$ 程度が適当である。

この方法を使って混合脂肪酸メチル中のペトロセリン 酸メチルを定量した例を Table-2 に示す。上記のどの 計算式を使っても大体一致した值が得られた。また酸化 法 (Table-2 脚注参照)による定量值とも一致した。

\section{5 試料の回収}

試料メチルエステル 7〜30mg, シフト試薬，及び TMS を含む NMR 測定後の四塩化炭素溶液 $0.2 \sim 0.4 \mathrm{ml}$ に $6 \mathrm{~N}$-塩酸 $2 \mathrm{ml}$ とエーテル $5 \sim 10 \mathrm{ml}$ を加え, ふりまぜ た後, 5 回水洗を繰り返し，エーテル層を分離した。エ 一テル層は, 硫酸ナトリウム (無水物) で脱水後, 溶媒を 留去し，試料エステルを回収した。これを GLC（固定 液相 DEGS, 温度 $205^{\circ} \mathrm{C}$ ) 及び TLC (シリカゲルG プ レート, 溶媒ヘキサンーエーテルー䣷酸 $(70: 30: 1))$ で分 析したところ，もとのメチルエステルのみが回収され， シフト試薬及び TMS が除かれていることを確認した。 この回収メチルエステルをさらに精製単離するには, 上 記の TLC を利用するのが適当で京る。

\section{4 考察}

シフト試薬を用いる脂肪酸の構造研究は, 本実験に使 ったような，特に高性能でもない普及機種を用いた場 合，とりわ効果的であるように思われる。著者らも $\mathrm{Eu}(\mathrm{fod})_{3}$ を用い，以上の基礎的な知見をもととして， 複雑な構造のアシルオキシポリアセチレン酸メチルの構 造決定に有効に利用することができた7)。

$\operatorname{Pr}(\mathrm{fod})_{3}$ を用いた例は $\mathrm{Eu}(\mathrm{fod})_{3}$ の場合ほどまだ多 くはないが，このシフト試薬も極めて有効に利用でき る。特に $\mathrm{Eu}(\mathrm{fod})_{3}$ とは反対に高磁場側へプロトンの シグナルが移動する点が貴重であり，二重結合及びその 周辺のプロトンのシグナルと，他のメチレン及びメチル プロトンとのシグナルを完全に分離するのには効果的で あって，定量の目的には都合がよい。ただし前述のよう に, $\operatorname{Pr}(\text { fod })_{3}$ の添加許容量は $\mathrm{Eu}(\text { fod })_{3}$ の場合よりも 小さく,メチルエステルに対し等モル程度までであっ て，それ以上の添加による著しいシフト効果は認められ なかった。

この実験の条件では，実用的に完全に区別をつけうる 脂肪酸のメチレンプロトンは，不飽和結合近辺のものの ほか，C-5 及びそれよりカルボキシル基に近いメチレン プロトンであって，それ以外のメチレンプロトンのシグ ナルは重なって分離しないが, 重水素化された $\mathrm{Eu}(\mathrm{fod})_{3}$ $-d_{30}$ や $\operatorname{Pr}(\mathrm{fod})_{3}-d_{30}$ を用いることによって, シフト試 薬自身のプロトンによる妨害がなくなり,さらに分離精 度が増すものと思われる。

シフト試薬の増加は, プロトンシグナルの移動の増大 をもたらすが，反面ピークの幅も増大し，その先鋭度を 減ずる。ことに混合脂肪酸メチルの場合は, 脂肪酸の種 類によって, 各相当プロトンのシフト值にいくらか差が
出てくることがあるので，シフト試薬を比較的多量添加 したときの各ピークの多重線の先鋭度は失われやすい。

脂肪酸の分析には，この報文のようにメチルエステル としてNMRにかけることが望ましい。四塩化炭素に対 する溶解度がよい壮かりではなく，エステルメチルの明 りょうな一重線が，シフト試薬を加えたよきの他のプロ トンのシフト傎の定性的指標となりうるふらである。さ らにこの一重線は, 脂肪酸炭素领部の構造の相異によっ て, シフト試薬添加の場合に, 各脂肪酸メチルでシフト 值に差が生じることが多い。この現象と，シフト值に変 動が少ない二重結合周辺のプロトンのシグナレ上を利用 して，脂肪酸の定量が可能となった。

実用的な定量精度の面と, 武料唯比較的多量 (7 mg 以上）必要とする点でに GLC に劣るが，圾料が完全に 回収できる点が利点である。ことに GLC では分離困難 なオレイン酸とペトロセリン酸の分離, 定量には効果的 であった。なお NMR を利用する一般飽和，不飽和脂 肪酸の定量は古くから試みられてはいるが，シフト試薬 発見以前のため，充分な成果はあげられていない(17),18。

以上のような脂肪酸メチルに対するシフト試薬添加に 関する基礎的知見索もととして，この方法が脂肪酸の構 造研究のみならず，定量その他の新しい忘用法の開発俘 も発展していくことが期待される。

(呮和 54 年 1 月 17 日受理)

\section{文献}

1) D. Swern, J. P. Wineburg, J. Am. Oil Chcm. Soc., 48, 371 (1971)

2) G. J. Boudreaux, A. V. Bailey, V.W. Tripp, J. Am. Oil Chem. Soc., 49, 200 (1972)

3) J. P. Wineburg, D. Swern, J. Am. Oil Chem. Soc., 49, 267 (1972)

4) D. J. Frost, I. Sies, Chem. Phys. Lipids, 13, 173 (1974)

5) J.P. Wineburg, D. Swern, J. Am. Oil Chem. Soc., 50, 142 (1973)

6) J. P. Wineburg, D. Swern, J. Am. Oil Chem. Soc., 51, 528 (1974)

7) K. Ichihara, T. Kawai, M. Kaji, M. Noda, Agr. Biol. Chem., 40, 353 (1976)

8) N. Ikeda, K. Fukuzumi, J. Am. Oil Chem. Soc., 51, 340 (1974)

9) P.E. Pfeffer, H. L. Rothbart, Tetrahedron Lett., 25, $2533(1972)$

10) Y. Wedmid, C. Litchfield, Lipids, 10, 145 (1975)

11) D. J. Frost, J. Bus, R. Keuning, I. Sies, Chem. Phys. Lipids, 14, 189 (1975)

12) J. Bus, C. M. Lok, A. Groenewegen, Chem. Phys. Lipids, 16, 123 (1976)

13) Y. Wedmid, C. Litchfield, Lipids, 11, 189 (1976)

14) C. R. Smith, Jr., R. V. Madrigal, D. Weisleder, R.D. Plattener, Lipids, 12, 736 (1977)

15) E. P. Jomes, J. A. Stolp, J. Am. Oil Chem. Soc., 35, 71 (1958)

16) E.P. Jones, V. L. Davison, J. Am. Oil Chcm. Soc., 42, 121 (1965)

17) W. H. Storey, Jr., J. Am. Oil Chem. Soc., 37, 676 (1960)

18) C. A. Glass, H. J. Dutton, Anal. Chem., 36, 2401 (1964) 